\title{
MANAJEMEN PROYEK DALAM PEMBANGUNAN BERWAWASAN LINGKUNGAN BERKELANJUTAN (STUDI PEMBANGUNAN MASJID KAMPUS II FIP UNIVERSITAS NEGERI MALANG)
}

\author{
Kusnul Prianto \\ Program Studi Arsitektur, Universitas Islam Negeri Sunan Ampel, Jl. Jend. A. Yani 117 Surabaya \\ Email: priantokusnul@gmail.com
}

\begin{abstract}
ABSTRAK
Proses manajemen proyek konstruksi dalam pembangunan yang berwawasan lingkungan dapat menjadikan kontrol untuk mewujudkan proses perencanaan, pelaksanaan, maupun pengawasan sesuai dengan tujuan yang diharapkan. Perencanaan merupakan salah satu bagian dari manajemen konstruksi untuk menghasilkan produk rancangan yang berkelanjutan. Proses perencanaan itu sendiri memiliki bagian-bagian tersendiri yang membutuhkan beberapa tenaga ahli untuk merumuskan desain, proses yang terjadi dalam rangkaian kegiatan tersebut tentunya melibatkan banyak pihak, baik secara langsung maupun tidak langsung. Pembangunan berkelanjutan yang berwawasan lingkungan (PBBL) memiliki turunan yaitu dokumen konstruksi Indonesia 2030. Dalam dokumen konstruksi tersebut menyatakan bahwa Indonesia harus berorientasi untuk tidak menyumbangkan kerusakan lingkungan namun harus menjadi pelopor perbaikan dan peningkatan kualitas lingkungan. Pembangunan Masjid kampus II Fakultas Ilmu Pendidikan Universitas Negeri Malang berusaha menerapkan konsep pembangunan yang berwawasan lingkungan. Perencanaan masjid tersebut berusaha untuk sehemat mungkin dalam memakai material yang dapat merusak lingkungan begitu juga pada masa pelaksanaannya. Penggunaan material didalam proses pembangunan masjid kampus II Fakultas Ilmu Pendidikan telah memenuhi kaidah material yang berwawasan lingkungan, mulai dari penggunaan material untuk pekerjaan pengecoran, rangka atap, kusen dan daun pintu, material finishing, infrastruktur penunjang dan pekerjaan sanitasi. Manajemen proyek konstruksi didalam proses perencanaan yang berwawasan lingkungan (berkelanjutan) sangat penting diterapkan terutama untuk menganalisa secara ekonomis terhadap material yang akan digunakan secara jangka panjang terhadap keberlangsungan lingkungan di sekitarnya.
\end{abstract}

Kata kunci: manajemen proyek, lingkungan, berkelanjutan

\section{PENDAHULUAN}

Pembangunan berwawasan lingkungan sering disebut juga dengan pembangunan berkelanjutan, dimana bertujuan untuk meningkatkan kesejahteraan masyarakat, melestarikan sumberdaya alam yang tersedia, dan menjamin keberlangsungan kehidupan lingkungan disekitarnya. Konsep pembangunan berkelanjutan mencakup tiga pilar utama yang saling terkait dan menunjang, yaitu pembangunan ekonomi, pembangunan sosial, dan pelestarian lingkungan hidup (KTT Bumi, 1992). Pertemuan tersebut menyepakati pola pembangunan baru yang diterapkan secara global yang disebut Environmentally Sound and Sustainable Development (ESSD), dimana di Indonesia dikenal dengan istilah Pembangunan Berkelanjutan yang Berwawasan Lingkungan (PBBL).

Pembangunan berkelanjutan yang berwawasan lingkungan (PBBL) memiliki turunan yaitu dokumen konstruksi Indonesia 2030. Dalam dokumen konstruksi tersebut menyatakan bahwa Indonesia harus berorientasi untuk tidak menyumbangkan kerusakan lingkungan namun harus menjadi pelopor perbaikan dan peningkatan kualitas lingkungan. Concil International du Batument, (1994) menyatakan bahwa tujuan sustainable construction adalah menciptakan bangunan berdasarkan desain yang memperhatikan ekologi, menggunakan sumberdaya alam secara efisien, ramah lingkungan selama masa pelaksanaan pekerjaan. Du Plesis (2002) menyatakan bahwa bagian dari sustainable construction adalah green construction yang merupakan proses holistik yang bertujuan untuk mengembalikan dan menjaga keseimbangan antara lingkungan yang alami dan buatan, sedangkan USEPA (2010) mendefinisikan green construction merupakan praktik membangun dengan menerapkan proses yang memperhatikan lingkungan dan efisiensi sumbe daya sepanjang siklus hidup bangunan dari tapak untuk perencanaan, konstruksi, operasi, pemeliharaan, renovasi dan dekonstruksi. 
Proses manajemen proyek konstruksi dalam pembangunan yang berwawasan lingkungan dapat menjadikan kontrol untuk mewujudkan proses perencanaan, pelaksanaan, maupun pengawasan sesuai dengan tujuan yang diharapkan. Perencanaan merupakan salah satu bagian dari manajemen konstruksi untuk menghasilkan produk rancangan yang berkelanjutan. Proses perencanaan itu sendiri memiliki bagian-bagian tersendiri yang membutuhkan beberapa tenaga ahli untuk merumuskan desain, proses yang terjadi dalam rangkaian kegiatan tersebut tentunya melibatkan banyak pihak, baik secara langsung maupun tidak langsung. Hubungan antara pihak-pihak yang terlibat dalam suatu proyek dibedakan atas hubungan fungsional dan hubungan kerja.

Pembangunan Masjid kampus II Fakultas Ilmu Pendidikan Universitas Negeri Malang berusaha menerapkan konsep pembangunan yang berwawasan lingkungan. Perencanaan masjid tersebut berusaha untuk sehemat mungkin dalam memakai material yang dapat merusak lingkungan begitu juga pada masa pelaksanaannya. Proses perencanaan dilakukan dengan mengakomodasi kearifan lokal dari segi material dan tenaga kerja. Teknologi yang semakin berkembang secara signifikan juga memunculkan variatif pilihan material bangunan, diperlukan suatu perencanaan yang matang didalam menentukan material yang akan digunakan. Dengan perencaaan yang tepat maka akan menghasilkan bangunan yang sesuai dengan kaidah yang sudah ditentukan, dalam hal ini yang hemat dan ramah lingkungan.

Tujuan dari penelitian ini adalah untuk membahas lebih lanjut proses perencanaan dan pelaksanaan pembangunan masjid kampus II Fakultas Ilmu Pendidikan yang menerapkan prinsip manajemen konstruksi yang berwawasan lingkungan berdasar studi literatur.

Manajemen Proyek Konstruksi adalah suatu proses penerapan ilmu-ilmu manajemen didalam proyek konstruksi meliputi proses perencanaan, pelaksanaan, pengawasan, dan proses evaluasi hasil pekerjaan yang dilakukan secara sistematis dengan mengoptimalkan semua sumber daya yang tersedia. Karakteristik proyek konstruksi dapat dipandang dalam tiga dimensi, yaitu unik, melibatkan sejumlah sumber daya, dan membutuhkan organisasi. Kemudian proses penyelesaiannya harus berpegang pada tiga kendala (triple constrain), sesuai spesifikasi yang ditetapkan, sesuai spesifikasi yang ditetapkan, sesuai time schedule, dan sesuai biaya yang direncanakan. Ketiganya diselesaikan secara simultan. Ciri-ciri tersebut diatas menyebabkan industri jasa konstruksi berbeda dengan industri lainnya, misalnya manufaktur.

Tiga karakteristik proyek konstruksi adalah:

1. Proyek bersifat unik, keunikan dari proyek konstruksi adalah tidak pernah terjadi rangkaian kegiatan yang sama persis (tidak ada proyek yang identik, yang ada adalah proyek sejenis), proyek bersifat sementara, dan selalu melibatkan grup pekerja yang berbeda-beda.

2. Membutuhkan sumber daya (resources), setiap proyek konstruksi membutuhkan sumber daya dalam penyelesaiannya, yaitu pekerja dan "sesuatu" (uang, mesin, metoda, material).

3. Membutuhkan organisasi, setiap organisasi mempunyai keragaman tujuan dimana didalamnya terlibat sejumlah individu dengan ragam keahlian, ketertarikan, kepribadian dan juga ketidakpastian.

Suatu rangkaian kegiatan dalam proyek konstruksi dapat dibedakan atas 2 jenis, yaitu kegiatan rutin dan kegiatan proyek. Kegiatan rutin adalah suatu rangkaian kegiatan terus-menerus yang berulang dan berlangsung lama, sementara kegiatan proyek adalah suatu rangkaian yang hanya satu kali dilaksanakan dan umumnya berlangsung dalam jangka waktu yang pendek. Oleh karena itu suatu kegiatan proyek mempunyai awal dan akhir kegiatan yang jelas serta hasil kegiatan yang bersifat unik.

Proyek konstruksi dapat dibedakan menjadi dua jenis kelompok bangunan, yaitu:

Bangunan gedung, dengan ciri-ciri:

1. Proyek konstruksi menghasilkan tempat orang bekerja atau tinggal.

2. Pekerjaan dilaksanakan pada lokasi yang relatif sempit dan kondisi pondasi umumnya sudah diketahui.

3. Manajemen dibutuhkan, terutama untuk progressing pekerjaan.

Bangunan sipil, dengan ciri-ciri:

1. Proyek konstruksi dilaksanakan untuk mengendalikan alam agar berguna bagi kepentingan manusia.

2. Pekerjaan dilaksanakan pada lokasi yang luas atau panjang dan kondisi pondasi sangat berbeda satu sama lain dalam suatu proyek.

3. Manajemen dibutuhkan untuk memecahkan permasalahan.

Pembangunan berkelanjutan yang berwawasan lingkungan (PBBL) didefinisikan sebagai pembangunan untuk memenuhi kebutuhan saat ini tanpa mengurangi kemampuan genarasi mendatang untuk memenuhi kebutuhannya. Pembangunan berkelanjutan harus memperhatikan pemanfaatan lingkungan hidup dan kelestarian lingkungannya 
agar kualitas lingkungan tetap terjaga. Kelestarian lingkungan yang tidak dijaga, akan menyebabkan daya dukung lingkungan berkurang, atau bahkan akan hilang. Pembangunan berkelanjutan mengandung arti sudah tercapainya keadilan sosial dari generas ke generasi. Dilihat dari pengertian lainnya, pembangunan berkelanjutan sebagai pembangunan nasional yang melestarikan fungsi dan kemampuan ekosistem.

Pembangunan yang berkelanjutan harus mencerminkan tindakan yang mampu melestarikan lingkungan alamnya dengan ciri-ciri sebagai berikut:

1. Memberi kemungkinan pada kelangsungan hidup dengan jalan melestarikan fungsi dan kemampuan ekosistem yang mendukungnya, baik secara langsung maupun tidak langsung

2. Memanfaatkan sumber daya alam dengan memanfaatkan teknologi yang tidak merusak lingkungan

3. Memberikan kesempatan kepada sektor dan kegiatan lainnya untuk berkembang bersama-sama di setiap daerah, baik dalam kurun waktu yang sama maupun kurun waktu yang berbeda secara berkesinambungan.

4. Meningkatkan dan melestarikan kemampuan dan fungsi ekosistem untuk memasok, melindungi, serta mendukung sumber alam bagi kehidupan secara berkesinambungan.

5. Menggunakan prosedur dan tata cara yang memerhatikan kelestarian fungsi dan kemampuan ekosistem untuk mendukung kehidupan, baik masa kini maupun masa yang akan datang.

Salah satu aspek penting dalam konsep keberlanjutan adalah menjaga eksistensi material agar tetap tersedia di bumi pada masa-masa mendatang. Sebagian besar material konstruksi berasal dari sumber daya alam, apabila penggunaan material tersebut tidak secara efesien maka di masa mendatang pasti sumber daya alam tersebut akan habis. Perkembangan teknologi bahan bangunan pada akhir-akhir ini sangat cepat, dapat dijumpai secara signifikan adalah penerapan konsep reuse terhadap komponen/material bangunan dan recycle terhadap limbah konstruksi dan bongkaran bangunan (Augenbroe dan Pearce, 1998).

\section{METODOLOGI}

Penelitian ini melalui tahapan-tahapan yang tertuang dalam bagan pada gambar 1. Adapun metode yang digunakan adalah metode diskriptif berdasarkan kajian literatur.

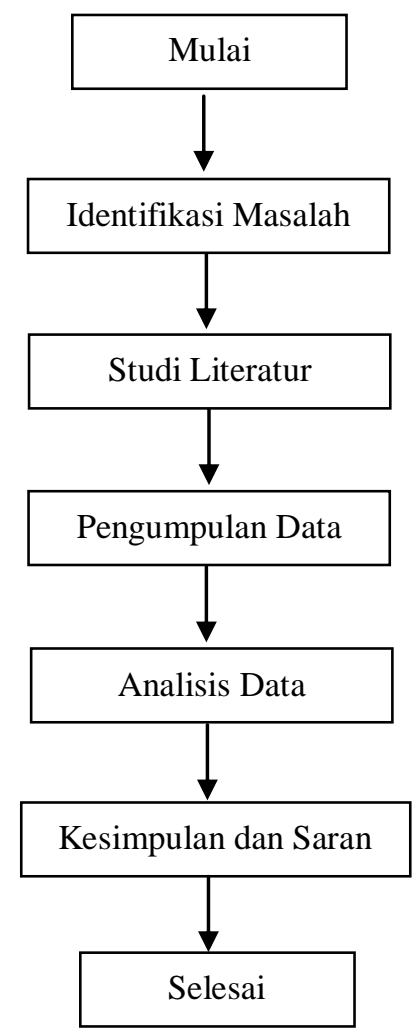

Gambar 1.

Bagan Alir Metodologi Penelitian 


\section{HASIL DAN PEMBAHASAN}

Pembangunan masjid kampus II Fakultas Ilmu Pendidikan Universitas Negeri Malang dilaksanakan dalam dua tahap pekerjaan. Tahap pertama adalah tahap pekerjaan struktur dan atap. Adapun rencana anggaran biaya untuk tahap pertama seperti pada Gambar 2. Pekerjaan tahap I pembangunan masjid ini meliputi pekerjaan persiapan, tanah, pasangan, penutup lantai dan dinding, beton, atap dan plafond, sanitasi, pengecatan, dan pekerjaan lain-lain. Mayor item pekerjaan yang terbesar terdapat dalam pekerjaan struktur dan rangka atap. Untuk pekerjaan struktur menggunakan beton dengan mutu K-250 pada pondasi dan beton mutu K-275 pada balok dan kolom.

Analisis penggunaan material yang ramah terhadap lingkungan telah dilakukan sejak masa perencanaan. Penggunaan begesting pada pekerjaan kolom dengan mengasumsikan dua kali pemakaian adalah salah satu tujuan agar bisa menghemat penggunaan papan triplek sebagai bahan utamanya dan kayu sebagai perancahnya, mengingat keberadaan kayu sampai saat ini yang sudah semakin jarang ditemukan di pasaran. Analisa pemakaian begisting dapat dilihat pada Gambar 3.

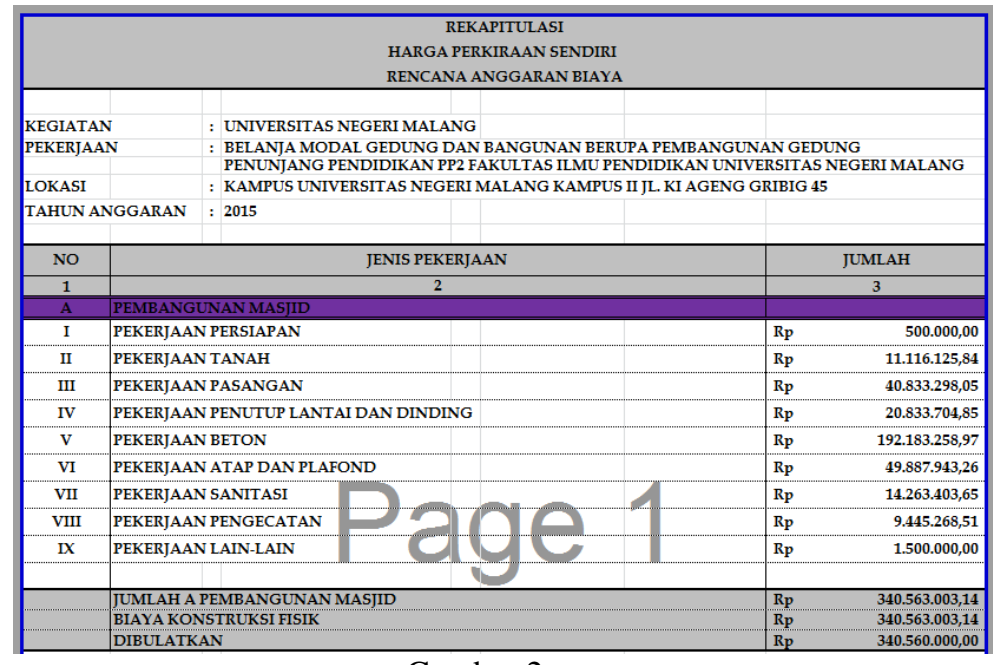

Gambar 2.

Rekapitulasi Tahap I Pembangunan masjid FIP (sumber diolah)

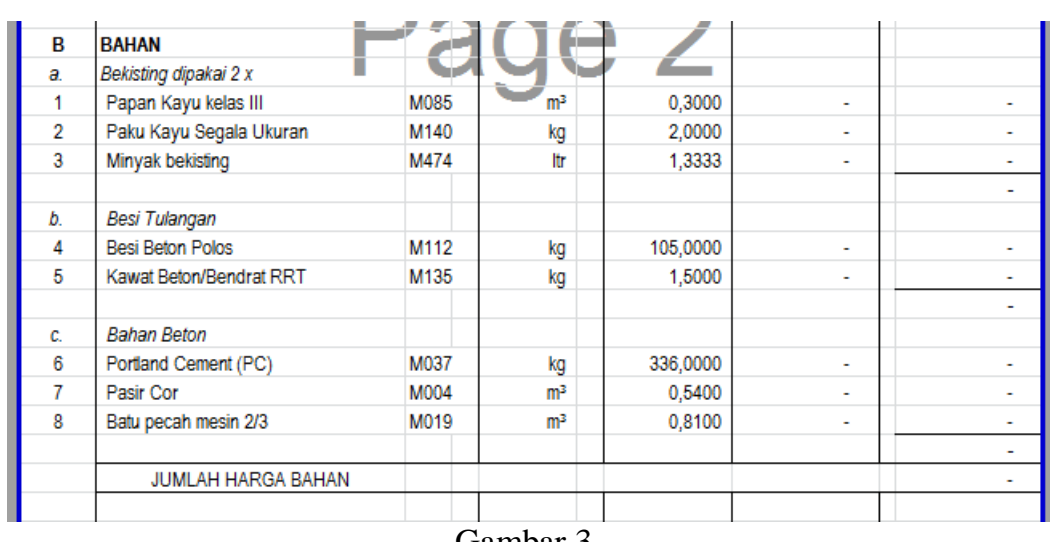

Gambar 3.

Analisa Begisting (sumber diolah)

Pekerjaan rangka pada pekerjaan ini telah direncanakan dengan memperhatikan kelestarian lingkungan, untuk rangka atap masjid ini menggunakan material baja profil C 150.50.2,3 sedangkan untuk usuk dan reng menggunakan material baja ringan ketebalan 0,75. Penggunaan material ini meliputi beberapa hal pertimbangan yaitu:

1. Material berbahan dasar kayu pada saat ini sudah mulai hilang di pasaran. Pembalakan liar tanpa memperhatikan keberlangsungan hidup material ini membuat material kayu susah didapatkan dan mahal harganya. Umur kayu juga tidak bisa bertahan lama pada suatu bangunan. 
2. Penggunaan material baja sebagai alternatif pengganti kayu sebagai struktur rangka atap memiliki kelebihan yaitu lebih kuat, anti keropos, anti rayap, umur konstruksi lebih lama, mudah dipasang, lebih ringan sehingga lebih efektif terhadap srtuktur dibawahnya. Secara ekonomis dengan waktu yang lebih lama penggunaan material baja maupun baja ringan ini lebih menguntungkan jika dibandingkan dengan penggunaan material kayu.

3. Namun demikian penggunaan material baja maupun baja ringan juga harus dihitung secara cermat secara strukturnya, artinya penggunaan baja pada struktur suatu bangunan harus efektif dan efisien, sesuai dengan fungsi dan kekuatan bangunan yang direncanakan.

Pada pekerjaan pasangan menggunakan batu bata yang secara geografis di wilayah Malang raya masih banyak didapatkan dan harganya masih relatif murah dibandingkan dengan menggunakan batu bata ringan. Konsep berwawasan lingkungan juga tidak bisa dilepaskan dengan prinsip manajemen proyek, sehingga konsep desain yang dihasilkan dalam suatu bangunan akan mendapatkan hasil desain yang berkelanjutan, berwawasan lingkungan, dan biaya yang dibutuhkan bisa maksimal sesuai dengan anggaran yang telah disediakan. Batu bata menurut NI-10, SII 0021-78 dijelaskan bahwa batu bata merupakan unsur bangunan yang diperuntukkan pembuatan konstruksi bangunan, dan dibuat dari tanah dengan atau tanpa campuran dengan bahan-bahan lainnya, dibakar dengan suhu cukup tinggi hingga tidak dapat hancur lagi jika direndam didalam air. Batu bata memiliki sifat karakteristik tahan api, kuat terhadap tekanan tinggi, daya serap air rendah, kedap suara, menyerap panas matahari secara signifikan.

Tahap II pembangunan masjid kampus II Fakultas Ilmu Pendidikan meliputi pekerjaan seperti pada Gambar 4. Pada tahap ini adalah tahap finishing untuk menyelesaikan pekerjaan tahap sebelumnya sehingga fungsional masjid ini bisa digunakan untuk fasilitas ibadah.

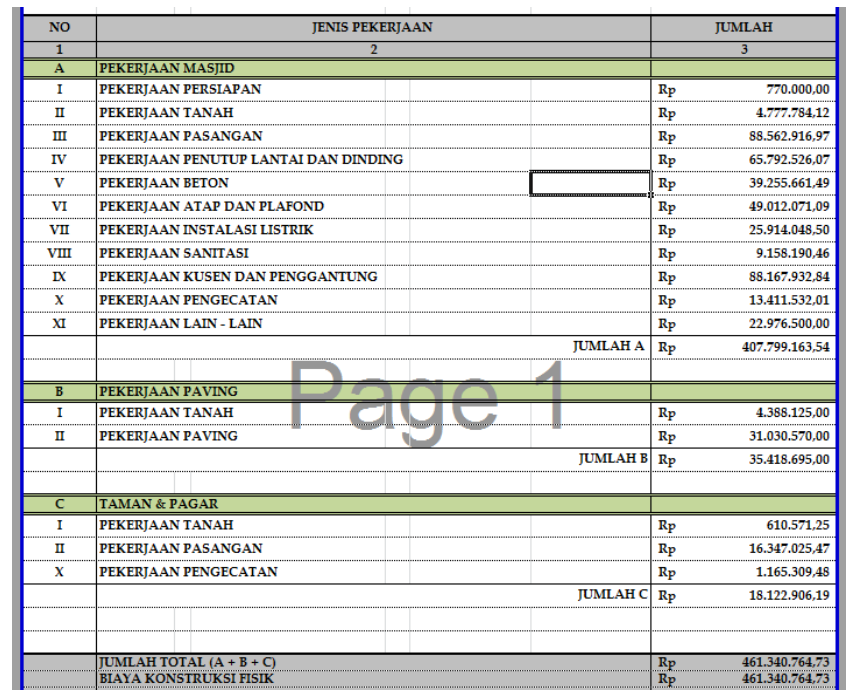

Gambar 4

Rekapitulasi Tahap II Pembangunan masjid FIP (sumber diolah)

Pekerjaan finishing penutup pasangan batu bata menggunakan material dari bahan pracetak, dengan dasar pemikiran sebagai berikut:

1. Bahan pracetak ini memiliki beban ringan sehingga tidak terlalu membebani dinding yang hanya berfungsi sebagai pengisi dari suatu komponen struktur bangunan,

2. Memiliki tampak sesuai dengan yang diinginkan, lebih hemat dalam waktu pengerjaan daripada membuat secara manual di lokasi pekerjaan,

3. Penggunaan material pracetak sangat ramah terhadap lingkungan dikarenakan tidak dibutuhkan pemakaian air yang banyak didalam proses pelaksanaannya.

Adapun bahan pracetak ini terbuat dari campuran antara semen, pasir dan air yang dituangkan didalam suatu cetakan yang telah didesain sesuai dengan gambar perencanaan. Hasil dari pracetak untuk penutup dinding bangunan masjid dapat dilihat pada Gambar 5. 


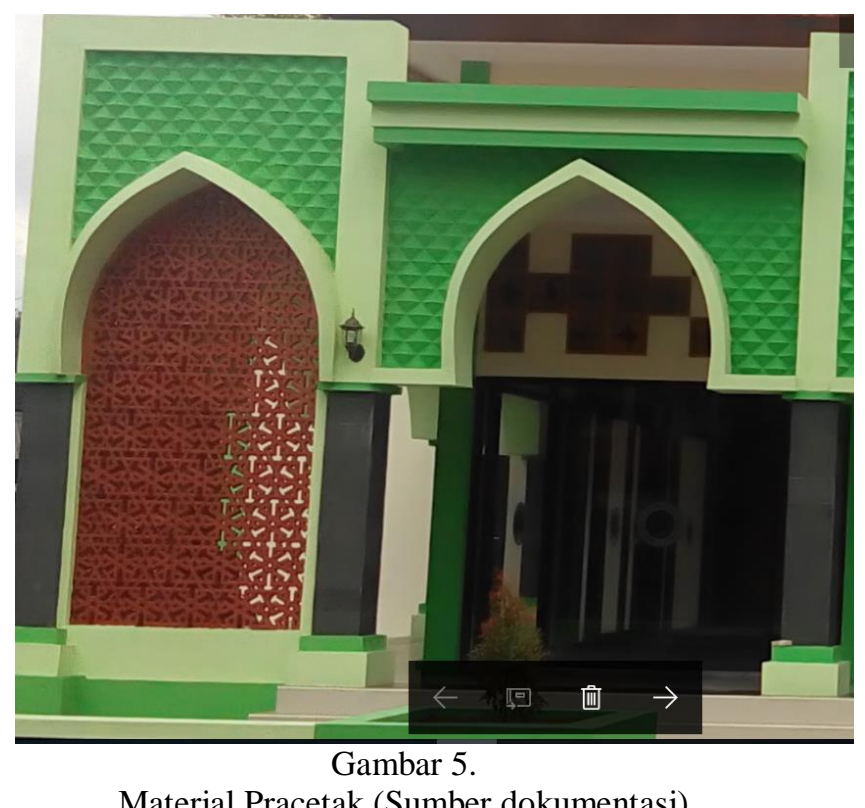

Prinsip dasar perencanaan masjid ini adalah sehemat mungkin didalam pemakaian bahan/material bangunan, energi yang digunakan, biaya yang sesuai dengan anggaran. Ventilasi alami adalah salah satu usaha yang direncanakan didalam proses perencanaan yang berwawasan lingkungan. Ventilasi alami adalah pergantian udara secara alami (tidak melibatkan peralatan mekanis, seperti mesin penyejuk udara yang dikenal dengan air conditioner atau AC), konsep ini menawarkan ventilasi yang sehat, nyaman, tanpa memerlukan energi tambahan. Untuk mendapatkan ventilasi alamai diperlukan beberapa syarat yang telah dipenuhi didalam perencanaan ventilasi alami (Prasasto Satwiko, 2008) pembangunan masjid, yaitu:

1. Tersedianya udara luar yang sehat (bebas dari bau, debu dan polutan lain yang mengganggu, kondisi di daerah Malang sudah memenuhi persyaratan ini, terlebih lokasi pembangunan masjid ini berada di tengahtengah areal kampus yang banyak terdapat pohon sebagai area terbuka hijaunya.

2. Suhu udara luar tidak terlalu tinggi (maksimal 28 derajat celsius), kondisi suhu di lokasi ini maksimal 28 derajat celcius, sehingga memenuhi untuk dibuat ventilasi alami.

3. Tidak banyak bangunan disekitar yang akan menghalangi aliran udara horisontal (sehingga aliran angin dapat berhembus lancar), lokasi pembangunan masjid ini terletak di lahan yang luas dan lapang sehingga memungkinkan lancarnya hembusan angin yang berada di area tersebut.

4. Lingkungan tidak bising, lokasi kampus II FIP ini berada di sebelah timur pusat kota Malang yang jauh dari kebisingan.

Arah sirkulasi angin dapat dilihat dalam Gambar 6. Penggunaan kisi-kisi sebagai jalan masuk dan keluarnya angin terbuat dari sisa-sisa potongan kayu yang tida terpakai. Pemanfaatan material sisa kayu ini sesuai dengan kaidah pembangunan yang berkelanjutan yaitu dengan menghemat bahan baku yang sudah mulai punah di alam ini. Dimensi dari kisi-kisi ini adalah $20 \mathrm{~cm}$ x $20 \mathrm{~cm}$ dengan jumlah pada masing-masing sisi bangunan 150 biji. Ketinggian plafond pada area sholat adalah $7 \mathrm{~m}$ pada tengah area, sehingga sirkulasi dari udara yang masuk dan keluar dapat berlangsung secara maksimal. 


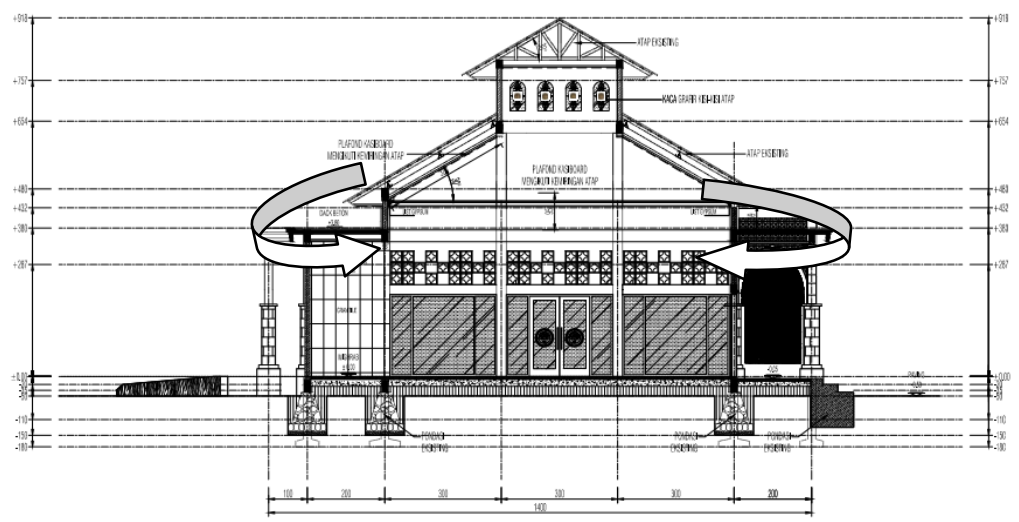

Gambar 6. Arah Sirkulasi Angin (sumber diolah)

Penggunaan material lainnya yang berwawasan lingkungan adalah kusen alumunium sebagai pengganti material kayu dengan pertimbangan bahwa material alumunium memiliki keunggulan dapat didaur ulang (reuse), bebas racun dan zat pemicu kanker, bebas perawatan dan praktis, dengan desain insulasi khusus mengurangi transmisi panas dan bising, hemat energi dan biaya, lebih kuat, tahan lama, anti karat, tidak perlu diganti sama sekali (hanya karet pengganjal saja yang perlu penggantian), tersedia dalam berbagai macam warna, bentuk dan ukuran sesuai dengan yang direncanakan, fleksibel sesuai dengan anggaran yang dianggarkan.

Sebagai material penunjang didalam melengkapi keberadaan masjid, sebagai penutup lantai area sekitarnya digunakan bahan paving blok, penggunaan material ini bertujuan untuk daya serap air hujan yang tinggi sehingga air bis langsung meresap kedalam tanah. Keberadaan air pada tanah dalam sangat perlu diperhatikan, karena akan menambah jumlah kadar air yang berada didalam tanah. Untuk finishing area terbuka hijau berupa tempat tanaman digunakan pasangan bata merah yang di expose untuk menonjolkan sifat natural pada konsep desain pembangunan masjid ini. Resapan air hujan disekitar pasangan paving blok juga digunakan sebagai area resapan air, sehingga air hujan yang turun dapat segera meresap edalam tanah.

Vegetasi yang direncanakan juga mendukung konsep pembangunan yang berkelanjutan sebagai salah satu penyuplai oksigen disekitar bangunan, sehingga ventilasi alami yang sudah direncanakan dapat terwujud sesuai dengan persyaratan yang telah diuraikan diatas tadi. Konsep pembangunan berwawasan lingkungan juga diterapkan didalam pekerjaan sanitasi yaitu dengan penggunaan septiktank dengan penyaring biologis berbahan fiberglass, dirancang khusus untuk tidak mencemari lingkungan, memiliki sistim penguraian secra bertahap, dilengkapi dengan sistim disinfektan, hemat lahan, anti bocor dan tidak rembes, tahan korosi, pemasangan mudah dan cepat, serta tidak membutuhkan perawatan khusus. Penguraian kotoran diproses secara bertahap secara biologis dan filterisasi bertahap melalui tiga kompartemen. Media kontak yang dirancang khusus dan sistim disinfektan sarana pencuci hama yang digunakan sesuai kebutuhan buangan limbah kotoran tidak menyebabkan pencemaran pada air tanah dan lingkungan.

\section{KESIMPULAN}

Kesimpulan dari penelitian ini sebagai berikut:

1. Penggunaan material didalam proses pembangunan masjid kampus II Fakultas Ilmu Pendidikan telah memenuhi kaidah material yang berwawasan lingkungan, mulai dari penggunaan material untuk pekerjaan pengecoran dalam hal ini penggunaan begisting dua kali pakai sudah memenuhi kaidah ramah lingkungan, dikarenakan bahan material kayu yang sudah mulai langka keberadaannya, pemilihan material baja canal dan baja ringan sebagai struktur rangka atap dikarenakan memiliki kelebihan yaitu lebih kuat, anti keropos, anti rayap, umur konstruksi lebih lama, mudah dipasang, lebih ringan sehingga lebih efektif terhadap srtuktur dibawahnya. Secara ekonomis dengan waktu yang lebih lama penggunaan material baja maupun baja ringan ini lebih menguntungkan jika dibandingkan dengan penggunaan material kayu.

2. Kusen dan pintu alumunium sebagai pengganti material kayu dengan pertimbangan bahwa material alumunium memiliki keunggulan dapat didaur ulang (reuse), bebas racun dan zat pemicu kanker, bebas perawatan dan praktis, dengan desain insulasi khusus mengurangi transmisi panas dan bising, hemat energi dan biaya, lebih kuat, tahan lama, anti karat, tidak perlu diganti sama sekali (hanya karet pengganjal saja yang perlu penggantian), tersedia dalam berbagai macam warna, bentuk dan ukuran sesuai dengan yang direncanakan, fleksibel sesuai dengan anggaran yang dianggarkan. 
3. Penggunaan bahan pracetak pada proses finishing memiliki kelebihan diantaranya yaitu bebannya yang ringan sehingga tidak terlalu membebani dinding yang hanya berfungsi sebagai pengisi dari suatu komponen struktur bangunan, memiliki tampak sesuai dengan yang diinginkan, lebih hemat dalam waktu pengerjaan daripada membuat secara manual di lokasi pekerjaan, material pracetak sangat ramah terhadap lingkungan dikarenakan tidak dibutuhkan pemakaian air yang banyak didalam proses pelaksanaannya.

4. Manajemen proyek konstruksi didalam proses perencanaan yang berwawasan lingkungan (berkelanjutan) sangat penting diterapkan terutama untuk menganalisa secara ekonomis terhadap material yang akan digunakan secara jangka panjang terhadap keberlangsungan lingkungan di sekitarnya. Penerapan manajemen proyek konstruksi ini melalui beberapa tahap dimulai dari tahap pra desain, proses desain, proses pelaksanaan, proses pengawasan, dan proses evaluasi hasil desain.

5. Penggunaan material yang ramah terhadap lingkungan harus menjadi skala prioritas didalam penerapan proses perencanaan desain, dengan tetap mengikuti perkembangan teknologi material bahan bangunan dan memperhatikan tingkat fungsional desain yang direncanakan.

6. Pemilihan material yang ramah terhadap lingkungan juga harus mempertimbangkan kearifan lokal daerah yang menjadi objek pembangunan desain tersebut, sehingga dengan memaksimalkan potensi material yang berada didalam suatu daerah dapat mengangkat taraf hidup masyarakat di sekitarnya.

Dari penelitian ini dapat diambil saran sebagai berikut:

1. Perlunya mengkaji secara lebih dalam tentang biaya yang dibutuhkan didalam merencanakan desain yang berwawasan lingkungan dengan desain yang tidak memperhatikan lingkungan.

2. Proses manajemen konstruksi didalam pembangunan yang berwawasan lingkungan juga perlu ditinjau dari masa pelaksanaan dan pengawasan

3. Objek yang dikaji bisa lebih ditingkatkan kepada desain yang memiliki tingkat pencemaran lingkungan yang lebih tinggi, semisal gedung berlantai banyak (Apartemen, hotel, kondominium, rusunawa, dsb)

\section{DAFTAR PUSTAKA}

Augenbroe, G., dan Pearce, A.R., 1998, Sustainable construction in the United State of America: Aperpective to the year 2010, Georgia Institute of Technology, Georgia.

Iman, S. (1997). Manajemen Proyek dari Konseptual Sampai Operasional. Erlangga Jakarta.

Prasasto, S. (2008). Fisika Bangunan. ANDI Yogyakarta.

Wulfram I. Ervianto, Biemo W, S, Muhamamad Abduh, dan Sujarmanto.(2012). "Kajian Aspek Keberlanjutan Konstruksi Jembatan Selat Sunda". Seminar Nasional Teknik Sipil UMS.

https://id.wikipedia.org/wiki/Manajemen_konstruksi 